\title{
Women, resettlement and desistance
}

Gill Mclvor, University of Stirling and Scottish Centre for Crime and Justice Research

Chris Trotter, Monash University, Australia

Rosemary Sheehan, Monash University, Australia

\section{Abstract}

With the numbers of women imprisoned increasing across Western jurisdictions over the last 15 or so years, so too have the numbers of women returning to the community following a period in custody. Despite increasing policy attention in the UK and elsewhere to prisoner resettlement, women's experiences on release from prison have received limited empirical and policy attention. Drawing upon interviews with women leaving prison in Victoria, Australia, this article discusses the resettlement challenges faced by the women and highlights their similarity to the experiences of women leaving prison in other jurisdictions. Women had mixed (and predominantly negative) experiences and views of accessing services and supports following release, though experiences of parole supervision by community corrections officers were often positive, especially if women felt valued and supported by workers who demonstrated genuine concern. Analysis of factors associated with further offending and with desistance, points to the critical role of flexible, tailored and women-centred post-release support building, and, where possible, upon relationships established with women while they are still in prison. 
In recent years increasing attention has been paid in Western jurisdictions to the effectiveness of prisoner resettlement, refl ecting, in part, a recognition that the social exclusion of prisoners is likely to contribute to their continued involvement in crime (Social Exclusion Unit, 2002). Much practical (and empirical) attention to prisoner resettlement has focused principally or exclusively upon men (e.g. Maguire et al., 1996). However it is now widely recognized that women are likely to have different needs on leaving prison, with women's needs typically being more complex than those of men (Gelsthorpe and Sharpe, 2007).

Existing literature on women in prison suggests that female prisoners have a complex range of problems and needs (e.g. Loucks, 2004) that are not usually addressed while they are in prison (Morris et al., 1995). UK research on female resettlement indicates that most women leaving prison feel inadequately prepared for or supported on release (Hamlyn and Lewis, 2000; Morris et al., 1995) and that women's already fragile material circumstances can deteriorate further while they are in prison (Carlen, 2003; Eaton, 2003; Niven and Stewart, 2004). For example it has been estimated that around one-third of women lose their accommodation when in prison (Gelsthorpe and Sharpe (2007), while the precarious (and often totally unsuitable) nature of women's post-release accommodation has been highlighted consistently by research (Morris et al., 1995; Niven and Stewart, 2004) and may result in some women returning to living arrangements where they have had prior experiences of physical and sexual abuse (Wilkinson, 2004).

A high proportion of female prisoners report prior substance misuse (e.g. Singleton et al., 2005), yet women report significant barriers to accessing appropriate drug treatment and support when they leave prison (Fox et al., 2005; MacRae et al., 2006), not least because women are generally considered by drug agencies to be a hard-to-reach group that is reluctant to engage with drug services (MacRae et al., 2006) through fear of losing their children (Fox et al., 2005). Given that much 
female crime is economically motivated (to support drug use or survive poverty), fi nancial difficulties can impinge upon women's ability to re-establish themselves in the community after prison (Gelsthorpe and Sharpe, 2007; Hamlyn and Lewis, 2000), with a breakdown in pre-existing relationships with partners often compounding their financial problems on release (Morris et al., 1995).

Previous research also suggests that employment, training and education in prison is ill-suited to equipping women for the outside job market (Hamlyn and Lewis, 2000; O'Keefe et al., 2007; Wilkinson, 2004) and that post-release employment is rarely an immediate concern for women on release from prison since other pressing issues (such as drug use, accommodation and regaining custody of children) need to be resolved first (Gelsthorpe and Sharpe, 2007; MacRae et al., 2006; O’Keefe et al., 2007). This, as Hester and Westmarland (2004) have similarly argued in with respect to women exiting prostitution, suggests that the sequencing of services and support is crucial: women require an appropriate range of multi-agency support at the right time.

The unprecedented increase in rates of female imprisonment across Western jurisdictions in the last 15 or so years (Mclvor, 2007) means that the needs of women in prison - and after - are increasingly difficult to ignore, raising questions as to how well existing community-based services are able to meet female ex-prisoners' needs and whether there are implications for women's desistance from crime. However, much of what is know about women's experiences of resettlement has been derived from research conducted in the UK, with relatively little attention thus far paid to this issue in other jurisdictions that have likewise experienced increases in female incarceration.

Australia, like the UK, has witnessed a large rise in female imprisonment rates over the last 10-15 years. For example, between June 1996 and June 2006 the number of female prisoners increased by 90 per cent (from 964 to 1827) (Australian 
Bureau of Statistics, 2006). In the state of Victoria there was a 76 per cent increase in the average number of female prisoners between 1995-2001 (Victoria Department of Justice, 2001), despite Victoria being widely acknowledged to be the most liberal Australian state with regard to the sentencing of offenders (Australian Bureau of Statistics, 2008). This article draws upon data from a study of women released from prisons in Victoria between December 2003 and December 2004 (Trotter et al., 2006)1 that examined their experiences of accessing services in custody and their experiences of resettlement on release. Just as research conducted in the UK suggests that women released from prison face signifi cant diffi culties reintegrating into society, and that imprisonment may service to further marginalize already socially excluded women, this analysis indicates both that problems associated with the resettlement of female prisoners are not confined to the UK and that barriers to resettlement may impact upon women's success in desisting from crime.

\section{Methods and sample}

The women who participated in the study were imprisoned either in the Women's Correctional Centre at Deer Park on the outskirts of Melbourne or in Tarrengower women's prison situated in a rural area about 136 kilometres from Melbourne. Prerelease interviews were conducted with 139 women serving sentences of at least three months and follow-up interviews were conducted approximately three and 12 months after release with sub-samples of 83 and 69 women respectively.

The women who were interviewed in prison prior to release varied from 17 to 67 years of age, with an average of age of 31 years. Eighty-four per cent were born in Australia, four per cent in Vietnam and three per cent each in other Asian countries and in New Zealand.2 The most common offences for which they were imprisoned were trafficking drugs $(13 \%)$, burglary $(11 \%)$, theft $(11 \%)$, robbery $(10 \%)$, fraud $(9 \%)$ and shoplifting (9\%). Fifteen women (11\%) were in custody as a result of a previous breach of parole and police records indicated that 63 per cent of the sample had 
been in prison before. Thirty per cent of the women indicated that they were either married or had been living in a de facto relationship at the time of their admission to prison. Fifty-nine per cent had dependent children, who were most often being cared for by their father or by maternal grandparents while their mothers were in prison.

This article focuses in particular upon data derived from the 12 month interviews, 22 of which were conducted in custody because the women were back in prison. These interviews sought to explore women's experiences on release from prison, including problems encountered, services and supports accessed (and their perceived effectiveness) and involvement in further criminal behaviour. The study thus permitted an exploration of the relationship between women's resettlement experiences and desistance from crime.

\section{Findings}

\section{Experiences after prison}

Prior to release, most of the women (128/139) felt that to aid their resettlement they would need to access services on their release from prison, around half of whom (58) thought that they would need to make use of a range of services. The risk of further drug use was the challenge most commonly anticipated by women (identifi ed by 31 women) followed by obtaining suitable housing ( 16 women). Eight women identified problems relating to family conflict, while seven were concerned about the prospect of unemployment, seven identifi ed a likely absence of general support on release and six believed that resuming friendships would present a challenge. In broad terms, therefore, the Victoria findings were in accord with fi ndings from previous studies of women leaving prison in the UK.

Further detailed analysis revealed the extent and nature of the challenges women faced after they had been released from prison. These were also reflected in the adjectives women used to describe how they had felt since leaving prison. While 
some women described their post-release experiences in positive terms overall (using adjectives such as 'exhilarating', 'happy', 'positive', 'fulfi lling' and 'good') others emphasized the fluctuating nature of their experiences (for example, 'fantastic some of the time', 'a hell of a ride', 'up and down' and 'turbulent') and others alluded to the struggles they faced coping with life after prison. The majority of women, however, described how they had felt in essentially negative terms, using expressions such as 'fucked up', 'lost', 'angry', 'unhappy', 'confused', 'insecure', 'miserable' and 'sad'. Two adjectives were particularly prominent in the women's accounts of their experiences: 'stressful' and 'lonely'. The former appeared to derive from both the practical and emotional struggles that the women encountered after prison, while the latter was often a consequence of broken relationships or active endeavours on the part of women to avoid relationships that were associated with their previous involvement in crime.

It was clear from the women's accounts of their post-release experiences that avoiding becoming drawn back into drug use was a key challenge for many. Despite their best intentions, many of the women experienced relapses and many were critical of the lack of available services and supports in relation to substance misuse. As we shall see, continued drug use was a significant barrier to women's ability to desist from further crime and the resumption of drug use was usually attributed to the influence of partners, friends and acquaintances, to boredom and to the stresses associated with managing everyday life. Some women who had used drugs (primarily heroin and methamphetamine) prior to their imprisonment had managed to remain drug free after their release or had had only a brief relapse, despite some having encountered other problems - such as close family bereavements and relationship breakdowns - that severely tested their resolve. For those who were motivated to become and remain drug free, accessing appropriate treatment and support programmes was often difficult and women reported lengthy, time-consuming journeys to obtain prescribed methadone especially, though not exclusively, beyond the Melbourne metropolitan area. 
Next to problems relating to drug use, the most common difficulty that women anticipated having when they were released from custody was fi nding suitable housing. Some women who were interviewed in prison prior to release anticipated being homeless and one indicated that she might be forced to return to an abusive relationship with her husband unless she was able to obtain alternative accommodation on release. Another woman who faced being homeless believed she would have limited support when she left prison because her only supports on the outside - her boyfriend and brother - were themselves currently serving custodial sentences.

Women's concerns about accommodation while in prison were reflected in their experiences upon release. Relatively few women moved into settled accommodation when they left prison, with only 27 women (39\%) still living at the same address they were released to a year later. Around a quarter of women (18 or $26 \%)$ reported having had at least four different addresses since their release and some described periods of homelessness, including sleeping in squats, caravans and cars. Women often moved into transitional accommodation from prison or stayed with friends and families until they could find accommodation of their own, though the process of obtaining reasonably stable accommodation appeared to be protracted. Moreover if women did not have children (or did not currently have care of their children) they were not deemed to be in priority housing need and were required instead to obtain private rented accommodation which many could not afford.

Women who were allocated transitional housing as an interim measure before obtaining more settled living arrangements often identified a range of problems with their accommodation. Several expressed concern for their safety or that of their family and friends in areas where drug use and crime were rife, and some recounted experiences of personal victimization, including vandalism, threats of 
violence and theft. Being accommodated in areas characterized by high levels of drug use also meant that women were in close proximity to users thereby increasing the likelihood of relapse. Two women explained that they had been allocated temporary housing in areas with poor public transport links, which resulted in feelings of isolation. Other women complained that the housing they were allocated was too small, of poor quality or in other ways unsuited to women with children.

Although the transitional nature of women's accommodation was a common reason for women not remaining in the accommodation they moved to after prison, women also identified other reasons for having unsettled living arrangements including the need to escape violent and abusive relationships, resumption of drug use and financial problems/debts. The breakdown of relationships with partners sometimes resulted in women having to seek alternative accommodation. In other cases women described having to remain in abusive relationships because they had nowhere else to go.

While some women were happy with the support they received from a range of agencies in obtaining alternative accommodation, others were critical of the perceived lack of support and of the difficulty in accessing stable accommodation through the Ministry of Housing. There was a perception among some women that agencies were only able to help those in the most troubled circumstances. As one woman explained, 'I don't have a bad enough track record. I haven't had enough dramas in my life to get Ministry of Housing. I've been told I'll have to get private rental which I can't afford'. Some women identified a lack of suitable accommodation as the factor that had most hindered their ability to resettle successfully after prison.

Around three-fifths of the women who were interviewed prior to release (59\%) had dependent children. While women with children were serving their sentences, the children were most often cared for by their fathers ( 22 cases), by their grandparents 
(22 cases) or by other family members or friends ( 7 cases). Ten women

who were interviewed pre-release reported that their children were in foster care while in thirteen cases siblings had been split up and were subject to a variety of living arrangements.

In most cases women hoped to resume care of their children on release, though parenthood was thought by some women as being likely to bring with it additional responsibilities and stresses. Most women were, indeed, reunited with their children when they left prison, though in some cases women had either lost or had signed over residence rights. Some women were content to allow their children to remain in alternative living arrangements until they felt they were 'stable' and better able to cope. As one woman commented:

Originally I was hoping that they'd all want to move in straight away, but I knew that wouldn't happen. It would be a big break from their dad. I would love them all to move in, but I don't know how l'd cope if they did all move in.

Other women were actively engaged in efforts to be reunited with children who were being looked after by the authorities (Department of Human Services) or living with their fathers or other family members and several commented that the process of resuming care of their children was taking much longer than anticipated. For some women, proving that they were drug-free - through regular urine tests - was a pre-condition of having their children returned to their care.

Women who remained separated from their children suggested that this was a source of significant distress. One woman, for example, explained that one of her greatest sources of concern had been 'not being able to see my daughter: sometimes I'd just call my dad and bawl on the phone for hours and say "I just want to run away"'. However, women who had resumed care of their children sometimes reported that this had not been without its problems: children - particularly those in their early teens - were sometimes difficult to manage and a source of considerable 
fi nancial strain.

Before leaving prison, women had often expressed concern about the fi nancial situation they were likely to find themselves in on release and the implications for their ability to provide for their children. Some reported having debts that had worsened while they were serving their sentence: this included one woman who had received an $\mathrm{A} \$ 1300$ gas bill that had been run up while she was in prison. It was clear from the 12 month interviews that many women had struggled fi nancially since leaving prison and, despite the success of recent initiatives aimed at enhancing the employability of female ex-prisoners in Victoria (McPherson, 2007), relatively few reported that they had previously been or were currently employed.

Not all women identified employment as a pressing priority, however, and it was considered by some women not to be feasible if they were still trying to deal with drug or alcohol problems or were subject to intensive community based supervision (either as parolees 3 or through further court orders) that entailed regular and frequent appointments with community corrections officers and other service providers.

A few women acknowledged that without paid work their financial circumstances led them to commit offences - such as shoplifting and other types of acquisitive crime - to provide for themselves and their children. Occasionally women engaged in sex work to get money to survive.4 However, as research in the UK has also indicated (e.g. O'Keefe et al., 2007), women regarded having a criminal record (and, especially, having been in prison) as a key barrier to employment. This was highlighted particularly in rural areas where it was more likely that potential employers and colleagues would be aware that women had been in prison. It also linked to two broader concerns that were manifested in a number of ways: adapting to 'normal' life and dealing with judgmental attitudes of potential employers, neighbours, family members and so on. 
In describing the challenges posed by adapting to life outside prison, women identified activities such as talking to people, shopping at the supermarket and doing other 'normal' things as presenting a source of personal stress. As one woman observed, in relation to the stigma she had experienced, 'you feel like everyone knows you're a jailbird'. For some this was most acute in the initial period after leaving prison but for others the difficulties had clearly lessened over time but nonetheless endured. The loneliness reported by several women was sometimes self-imposed for pragmatic reasons: to 'start afresh' away from the temptations presented by previous acquaintances. Often, however, women simply lacked the confidence to engage with other people, partly through feeling de-skilled in social interactions and partly through a concern about how others might react if they found out they had been in prison. As one woman explained:

Re-adjusting, trying to talk to people is really hard. Like, if you've lived the lifestyle for so long and then you don't want to see those people anymore and you have to meet totally new people. Like, what do you talk about? You strike up a conversation and they ask you what you've done before. You don't want to tell them, so you lie. And before you know it, it's snowballed.

Feelings of loneliness and isolation no doubt were exacerbated by and contributed to mental health problems amongst this sample of women. In addition to reporting experiences of 'stress', women identified a range of mental health problems including anxiety and depression (most common), schizophrenia, panic attacks, bi-polar disorder and anorexia nervosa. Physical illnesses and disabilities were also commonly reported including skin problems, hepatitis $\mathrm{C}$, diabetes, bronchitis, pneumonia, kidney problems, hormonal problems, abscesses and fractured limbs.

Despite the profound difficulties associated with resettlement that many women described, some women believed that they had, overall, coped well since leaving prison. As one woman explained: 
No drama. No issues whatsoever. I've settled back easily. ... It seems so far away now, it's just not an issue.

Usually women who had coped well had done so as a result - or at least with the assistance - of support they had received from partners, family, friends and a range of professionals (including counsellors, psychologists, parole offi cers and staff from a variety of not-for-profit organizations). However for other women, experiences of professional support on leaving prison were more mixed.

\section{Professional support}

In both of the prisons the women were offered a number of welfare programs including psychiatric and psychological services, housing, chaplaincy, anger management, parenting and education. Moreover, 32 per cent of women who were interviewed in prison had contact with welfare agencies prior to their imprisonment. On average, women who said they had had contact with welfare agencies prior to their current prison sentence had contact with more than three agencies.

Most women when interviewed in prison before release were confident that the services they needed to assist their resettlement would be available. However, as we have seen, the reality was often very different, with women often expressing disappointment at the response of organizations - especially public sector agencies - to their problems. Although 62 women interviewed after 12 months had had some contact with welfare agencies since their release from prison, the greatest support the women had received was usually said to have come from family members (most often mothers), partners and friends (Trotter et al., 2006).

Women had mixed views about how helpful the agencies they had had contact with since leaving prison had been. Some women were critical of community-based non-statutory services on the basis that they were too limited in scope (for example, 
time limited), inadequately resourced and insufficiently practical and proactive. Aspects of support that they particularly valued from these organizations, on the other hand, included the willingness of workers to provide practical support and assistance (such as referral to other agencies, assistance with completing housing applications and so on) across a range of issues (even if the agency purportedly had a narrower remit) and, if necessary, over an extended period of time. Women valued contact with support workers who appeared to take a genuine interest in them and who were open, easy to talk to and 'down to earth'.

Given the prevalence of drug problems among the sample of women, drug services received particular comment, with views again being mixed. Criticisms centred upon inexperienced (and hence easy-to-manipulate) practitioners, workers who did not keep appointments and services that were insufficiently focused on assisting women to gain insight into the nature and causes of their drug problems. Women were appreciative of organizations that were able to provide practical help regarding their drug problems (such as access to a methadone reduction programme), enthusiastic and helpful workers who appeared to take a real interest in them and other types of practical support aimed at enabling women to access a range of services - such as being accompanied to appointments at other agencies and occasional telephone calls to remind women of their appointments:

She went out of her way to help and to make things as convenient for me as possible.... I felt like it was important to her.... She's also rang me at home. She knows I'm a bit hopeless at remembering things so she'd ring and just check that I'd remembered my appointment time.

Just under half of the women interviewed in prison (64 or 46\%) were subsequently released on parole. Those on parole were required to meet regularly with their community corrections office (parole officer) and, unless they had children or full-time work, to undertake unpaid community work. Women who were paroled were significantly less likely than those released without parole to have been reconvicted 
or re-imprisoned and were less likely to report further offending, though

there may have been some selection bias as a result of not all women agreeing to provide access to their criminal records (Trotter et al., 2006; Trotter, 2007) and those granted parole having served longer sentences. However it also seems from their accounts that some of the women had benefited from the additional support provided by their parole officer and believed that it had helped them not to reoffend.

Parole officers were often viewed by women as having been helpful and supportive. However, less emphasis tended to be placed by women on what their parole officers did than on how they did it. Women appreciated having supervisors who were friendly, interested, committed, supportive and prepared to listen. Women also valued receiving positive feedback from their parole officers, being helped to link with other services and their worker's accessibility. One woman emphasized the effective balance that her community corrections officer had achieved between enforcement and support:

She had just about the right combination to be a parole officer. There are those who will ring the Jacks5 if you miss one appointment - they're just on a power trip. She's not fanatical but she's clear about her role and how far she can go and how far you can go.

The statutory responsibility placed upon parole officers to enforce licence conditions and respond to instances of non-compliance was an aspect of parole often regarded negatively by women. If women considered themselves in some instances to be 'going through the motions' with regard to parole, parole officers were sometimes thought to do likewise. Responsibility for enforcing parole licences meant that women often expressed mistrust of parole officers whom they regarded as being principally interested in monitoring their behaviour but otherwise disinterested in their wider needs. In this sense, parole officers were regarded by some women simply as 'another form of police'. 


\section{Resettlement and desistance}

One year after leaving prison, 36 women admitted having committed one or more further offences, while 23 claimed to have been crime-free.6 There were clear differences in the experiential accounts of women who had successfully desisted since leaving prison and those who had continued to offend. Many women attributed their desistance to their success in avoiding drug use since leaving prison, in some cases prompted by self-reflection about how they had been affected by drugs. For example, one woman (who had been using drugs for around 30 years) explained:

I felt like I was hitting gutter level. I was becoming an addict, not a user. The drug was using me. That's what stopped me. I've always preached this to people - 'don't ever let the drug use you'.

In a similar vein, another woman observed:

I have to look at my sister stoned or pilled. It makes me sick. She repeats herself three or four times. And I think to myself 'was I like that?'.

This enhanced self-awareness was in some cases linked to personal resolve to achieve and sustain a 'better' or 'normal' life and often involved taking active steps to dissociate from former lifestyles and associates and find new interests and friends. Supportive family relationships were identified by several women as having contributed to their desistance while concerns about the impact of continued offending on women's children also emerged as a dominant theme:

I'm not scared any more. I have support. I'm not scared to say 'no'.7 I don't ever want to go back there. I wouldn't disappoint myself again and wouldn't put my daughter through that again.

This is consistent with the wider literature on desistance which has identifi ed 
women's relationships (with children, parents or partners) as pivotal with respect to the process of desistance from crime (e.g. Mclvor et al., 2004; Barry, 2007).

Women who had continued to offend, on the other hand, often attributed this to the resumption of drug use in the period since leaving prison. Women's drug use was often attributed by them to 'hanging around with the wrong crowd', to boredom or to ongoing drug use by a partner or friend. However women also recounted a range of stressful experiences that had resulted in them turning to drugs, such as bereavement, redundancy, homelessness and relationship breakdown. As one woman explained:

Actually, it didn't start with drugs, it started with being homeless and the drugs came with that and basically it was just petty stuff to support myself.

Women usually attributed their involvement in acquisitive crime (mainly shoplifting but also robbery and burglary) to their drug use. However, financial hardship also featured as an explanation in some cases, with offending deemed necessary to meet basic everyday needs. Mental health issues - principally anxiety and depression - also featured in some women's accounts of how and why they re-offended. Some of these women described using illicit drugs (or illicitly obtained drugs) to selfmedicate, while others suggested that their offending was an expression of underlying anger or an inability to cope. These women tended to regard their offending as a 'cry for help' and prison as a way of accessing support for their problems. For example, one woman said 'I believe deep down I really wanted to get caught to go back to jail because I wasn't coping very well' while another explained:

I was pissed off and angry. I was not getting help for my anorexia and I was being bashed. I was walking down the road after an appointment with the Salvos 8 and I saw the car and just kicked it and kicked it and kicked the window and then thought 'fuck it, I'll take it' - if I go back to jail at least I'll get help there. 
Women's accounts of offending were often characterized by their purposefulness and agency (albeit under exceptionally constrained personal or social circumstances). However it was also not uncommon for women to allude to a significant lack of agency when describing their post-prison offending. The belief that they were in some sense victims of circumstances was reflected in comments such as I was just in the wrong place at the wrong time', 'one thing led to another' and 'I couldn't stop him from using so I ended up using too'.

The overarching theme that could be discerned from desisters, on the other hand, was the sense of personal agency and self-efficacy that characterized the accounts of these women. This contrasts starkly with the experiences of women who had struggled since leaving prison, who had continued offending, who were often in worse personal circumstances than they had been on release and who at best could be described as 'standing still'. The importance of self efficacy - refl ected in a changed perception of agency and self-worth - has also been highlighted by Hannah-Moffat (2003: 45) who concluded that:

A successful re-integration plan is one that moves towards autonomy and away from control by others. Research on women who manage to stay out of the system indicates that those most likely to 'succeed' take control of their lives and thus change directions.

\section{Discussion and conclusion}

While the women interviewed were not universally positive in their appraisal of parole supervision following release from prison, the support and structure provided by their community corrections officers and by staff from other non-statutory agencies were highly valued when they were perceived to address their practical and personal needs. The apparent relationship between effective post-release support and female desistance identified in this research is also supported by fi ndings from a number of US studies, including Pearl's (1998) finding that women on parole 
who made use of social services after their release had lower levels of recidivism, Zanis et al.'s (2003) finding of lower rates of recidivism (22\% compared to 34\%) among female prisoners with a history of drug use if they were paroled early to a community based drug treatment facility and Holtfreter et al.'s (2004) fi nding that community corrections officers who helped women with their housing needs had clients who offended less often.

In Australia, as in the UK, the majority of women released from are not subject to statutory supervision given the short prison sentences that most women typically receive9 though this may change with the implementation of the 'custody plus' sentence proposals contained in the Criminal Justice Act 2003 in England and Wales, which have attracted criticism with regard to their potential for 'netwidening' (Gelsthorpe, 2006; Player, 2005) and which have led Carlen to remind us that 'community reintegration and penal incarceration are two entirely different and opposed processes and ... the former cannot be invoked to justify the latter' (Carlen, 2003: 35).

In this context it is important to recognize that the women in Victoria who were subject to statutory supervision often expressed wariness with respect to the role of community corrections officers in enforcing parole requirements, suggesting that this created a barrier to open communication and helped to develop an atmosphere of mistrust. This perhaps indicates that effective engagement may be better achieved through voluntary take-up of services, though it has been well-documented that women are often reluctant to initiate contact with statutory social services unless required to do so - because of their previous experiences of social work involvement (for example, in the care system) and/or because they are fearful of their children being removed from their care if problems such as drug misuse come to light (Fox et al., 2005). This being so, non-statutory services may have a central role to play in supporting women on release. 
Women in Victoria also appreciated the willingness of some support workers to cross disciplinary boundaries and assist women to deal with a range of issues and problems. At a practical level, this meant that women could have easier access to a range of services through one initial contact point and could avoid the time and cost associated with having to make contact individually with a range of service providers. This has parallels with the 'one stop shop' model that is generating growing interest in the UK (e.g. Hedderman et al., 2008). It also has some resonance with the concerns expressed in the Corston Report (Corston, 2007) regarding the increasing fragmentation of resettlement services for women in England and Wales.

Together the findings from the present study and from other recent research into women's experiences of resettlement point to the importance of property coordinated and sequenced services for women leaving prison. Examples of innovative and holistic community provision currently exist in the UK, such as the Asha Centre in England (Roberts, 2002) and the 218 Centre in Scotland (Loucks et al., 2006; Malloch et al., 2008), and these provide models and lessons upon which other jurisdictions might usefully draw. Gender appropriate services such as these can provide the type of safe environment in which women can 'recover': as one woman in the Victorian study explained, 'I couldn't address my past trauma while I was living in trauma'. It is equally important, however, for the process of settlement to begin before women complete their prison sentences. In this way, meaningful and trustful relationships can be established that help to increase the likelihood that women are engaged by services immediately upon release from prison and helped to access the assistance and support that many so clearly require.

\section{Notes}

1 The study thus predated more recent policy initiatives introduced to improve the quality of services for female offenders in the state, many of which, disappointingly, focused on services within prisons rather than on diversionary 
measures (Victoria Department of Justice, 2005).

2 Three other women were born in Europe and one in Africa while in two further cases the country of birth was unknown.

3 Parole is at the discretion of the parole board but women are automatically considered for parole if their sentence is for 12 months or more and no women in the sample who were eligible were denied parole (one woman had her parole deferred but was subsequently released on parole). When paroled the women were expected to report to the parole officer within 48 hours of their release from prison. In all cases the women undertook intensive parole for the first three months of the parole period. This involved visiting the parole officer twice per week and undertaking one day per week unpaid community work (unless the women had children or full time work). The parole officer may also arrange an early visit to Centrelink (Social Security). Many of the women had special conditions and were legally required to be involved in programmes such as drug treatment, psychiatric treatment or cognitive behavioural programmes. The average period of parole for women released in 2003 was 416 days (unpublished data provided by Corrections Victoria Resource Centre, 2006).

4 Certain forms of prostitution have been legalized in Victoria but street-based sex work remains illegal (Mossman, 2007).

5 Police.

6 Ten women chose not to answer this question.

7 This woman had been persuaded to become involved in drug trafficking by a former partner.

8 Salvation Army welfare workers. 
9 Indeed, in Scotland eligibility for statutory supervision only applies to those serving sentences of four or more years and in $2007 / 8$ only $1 / 113$ receptions of young female prisoners and 20/829 adult female prison receptions involved sentences of this length (Scottish Government, 2008).

\section{References}

Australian Bureau of Statistics (2006) Prisoners in Australia, 2006. Canberra, ACT: Australian Bureau of Statistics.

Australian Bureau of Statistics (2008) Corrective Services Australia March 2008.

Canberra, ACT: Australian Bureau of Statistics.

Barry, M. (2007) 'The Transitional Pathways of Young Female Offenders: Towards a Non-offending Lifestyle', in R. Sheehan, G. Mclvor and C. Trotter (eds) What Works with Women Offenders. Cullompton: Willan Publishing.

Carlen, P. (2003) 'A Strategy for Women Offenders? Lock Them Up, Programme Them ... and then Send Them out Homeless', Criminal Justice Matters 53: 34-5.

Corston, Baroness (2007) The Corston Report: A Review of Women with Particular Vulnerabilities in the Criminal Justice System. London: Home Office. URL (accessed 14 September 2009): http://www.homeoffi ce.gov.uk/documents/corston-report/

Eaton. M. (1993) Women After Prison. Buckingham: Open University Press.

Fox, A., Khan, L., Briggs, D., Rees-Jones, N., Thompson, Z. and Owens, J. (2005)

Throughcare and Aftercare: Approaches and Promising Practice in Service Delivery for Clients Released from Prison or Leaving Residential Rehabilitation. Home Office Online Report 01/05. London: Home Offi ce. 
Gelsthorpe, L. (2006) 'Women and Criminal Justice: Saying it Again, Again and Again', The Howard Journal 45(4): 421-4.

Gelsthorpe, L. and Sharpe, G. (2007) 'Women and Resettlement', in A. Hucklesby and L. Hagley-Dickinson (eds) Prisoner Resettlement: Policy and Practice.

Cullompton: Willan Publishing.

Hamlyn, B. and Lewis, D. (2000) Women Prisoners: A Survey of their Work and Training Experiences in Custody and on Release. Home Office Research Study

208. London: Home Office. URL (accessed 14 September 2009): http://rds. homeoffi ce.gov.uk/rds/pdfs/hors208.pdf 
Hannah-Moffat, K. (2003) 'Getting Women Out: The Limits of Reintegration Reform', Criminal Justice Matters 53: 44-5.

Hedderman, C., Palmer, E. and Hollin, C. (2008) Implementing Services for Women Offenders and Those 'At Risk' of Offending. London: Ministry of Justice. URL (accessed 14 September 2009): http://www.justice.gov.uk/docs/togetherwomen. pdf

Hester, M. and Westmarland, N. (2004) Tackling Street Prostitution: Towards an Holistic Approach. Home Office Research Study 279. London: Home Offi ce.

Holtfreter, K., Reisig, M. and Morash, M. (2004) 'Poverty, State Capital, and Recidivism among Women Offenders', Criminology \& Public Policy 3(2): 181-216.

Loucks, N. (2004) 'Women in Prison', in G. Mclvor (ed.) Women Who Offend, London: Jessica Kingsley.

Loucks, N., Malloch, M., Mclvor, G. and Gelsthorpe, L. (2006) Evaluation of the 218 Centre. Edinburgh: Scottish Executive Social Research.

Mclvor, G. (2007) 'The Nature of Female Offending', in R. Sheehan, G. Mclvor and C. Trotter (eds) What Works with Women Offenders. Cullompton: Willan Publishing.

Mclvor, C., Murray, C. and Jamieson, J. (2004) 'Is Desistance from Crime Different for Women and Girls?', in R. Immarigeon and S. Maruna (eds) After Crime and Punishment: Ex-offender Reintegration and Desistance from Crime. Cullompton: Willan Publishing. 
McPherson, T. (2007) 'Employment: Offending and Reintegration', in R. Sheehan,

G. Mclvor and C. Trotter (eds) What Works with Women Offenders. Cullompton: Willan Publishing.

MacRae, R., Mclvor, G., Malloch, M., Barry, M. and Murray, L. (2006) Evaluation of the Scottish Prison Service Transitional Care Initiative. Edinburgh: Scottish Executive Social Research. URL (accessed 14 September 2009): http://www. scotland.gov.uk/Publications/2006/02/08110928/0

Maguire, M., Peroud, B. and Raynor, P. (1996) Automatic Conditional Release: The First Two Years. Home Office Research Study 156. London: Home Offi ce.

Malloch, M., Mclvor, G. and Loucks, N. (2008) “"Time Out” for Women: Innovation in Scotland in a Context of Change', The Howard Journal 47(4): 383-99.

Morris, A., Wilkinson, C., Tisi, A., Woodrow, J. and Rockley, A. (1995) Managing the Needs of Female Prisoners. London: Home Offi ce

Mossman, E. (2007) International Approaches to Decriminalising or Legalising Prostitution. Wellington, New Zealand: Crime and Justice Research Centre, Victoria University Wellington.

Niven, S. and Stewart, D. (2004) Resettlement Outcomes on Release from Prison in 2003. London: Home Office. URL (accessed 14 September 2009): http://rds. homeoffi ce.gov.uk/rds/pdfs05/r248.pdf

O'Keefe et al. (2007) 'Barriers to Employment, Training and Education in Prison and Beyond: A Peer-led solution', in R. Sheehan, G. Mclvor and C. Trotter (eds) What Works with Women Offenders. Cullompton: Willan Publishing. 
Pearl, N. (1998) 'Use of Community-based Social Services to Reduce Recidivism in Female Parolees', Women and Criminal Justice 10(1): 27-52.

Player, E. (2005) 'The Reduction of Women's Imprisonment in England and Wales', Punishment and Society 7(4): 419-39.

Roberts, J. (2002) 'Women Centred: The West Mercia Community Based Programme for Women Offenders', in P. Carlen (ed.) Women and Punishment: The Struggle for Justice. Cullompton: Willan Publishing.

Scottish Government (2008) Prison Statistics Scotland 2007/8. Edinburgh: Scottish Government.

Singleton, N., E. Pendry, T. Simpson, E. Goddard, M. Farrell, J. Marsden and C. Taylor (2005) The Impact of Mandatory Drug Testing in Prisons. Home Office Online Report 03/05. URL (accessed 14 September 2009): http://www. homeoffi ce.gov.uk/rds/pdfs05/rdsolr0305.pdf

Social Exclusion Unit (2002) Reducing Re-offending by Ex-prisoners. London: Social Exclusion Unit.

Trotter, C. (2007) 'Parole and Probation', in R. Sheehan, G. Mclvor and C. Trotter (eds) What Works with Women Offenders, Cullompton: Willan Publishing.

Trotter, C., Sheehan, R. and Mclvor, G. (2006) Women after Prison. Melbourne: Australia: Monash University School of Social Work. 
System 1995/1996 to 2000/2001. Melbourne: Victoria Department of Justice.

Victoria Department of Justice (2005) Better Pathways: An Integrated Response to Women's Offending and Re-offending. Melbourne: Victoria Department of Justice.

Wilkinson, C. (2004) 'Women's Release from Prison: The Case for Change', in G. Mclvor (ed.) Women who Offend. London: Jessica Kingsley.

Zanis, D., Mulvaney, F. and Coviello, D. (2003) 'The Effectiveness of Early Parole to Substance Abuse Treatment Facilities', Journal of Drug Issues 33(1): 223-35. 
